\title{
Hubungan Pemangkasan Organ bagian Atas Tanaman Jagung ( Zea mays, L ) dan Dosis Urea terhadap Pengisian Biji
}

\section{Surtinah}

\author{
Staf Pengajar Fakultas Pertanian Universitas Lancang Kuning
}

\begin{abstract}
Abstrak
Penelitian ini bertujuan untuk mendapatkan dosis Urea yang dapat memberikan pertumbuhan vegetatif yang terbaik pada tanaman jagung yang dipangkas daunnya bagian atas.

Rancangan lingkungan adalah rancangan acak kelompok dalam faktorial, analisa data mengunakan regresi polinomial. Hasil penelitian menunjukkan bahwa jumlah biji meningkat, begitu juga berat kering biji, namun kecepatan pengisian bahan kering ke biji, dan waktu pengisian bahan kering ke biji lebih cepat pada tanaman yang tidak dipangkas dibandingkan dengan tanaman yang dipangkas dengan pemberian Urea dengan dosis yang sama.
\end{abstract}

Kata kunci : Pemangkasan, Urea, Jagung, Polinomial, dan Bahan kering.

\section{PENDAHULUAN}

Biji merupakan produksi dari tanaman jagung, dimana ukuran biji merupakan salah satu komponen hasil yang sangat penting. Ukuran biji merupakan fungsi perkalian kecepatan pengisian bahan kering dengan lama waktu pengisisan efektif.

Biji jagung mempunyai kemampuan untuk menimbun bahan kering. Hal ini merupakan salah satu faktor penting dalam proses produksi, aspek fisiologis yang mempengaruhi perkembangan biji belum banyak dibahas. Perkembangan biji jagung dipengaruhi oleh beberapa hal antara lain adalah kondisi tanaman sebelum berbunga dan kondisi tanaman setelah berbunga.

Bahan kering yang disuplai ke dalam biji merupakan hasil metabolisme tanaman, namun apakah asimilat yang ditimbun tersebut merupakan asimilat sebelum berbunga atau setelah berbunga atau pada saat pengisian biji. Masalah ini perlu dikaji lebih dalam lagi , sehingga perlakuan-perlakuan yang diberikan untuk meningkatkan produksi jagung dengan tepat dapat ditentukan. Untuk meningkatkan berat kering, maka pertumbuhan vegetatif tanaman perlu ditingkatkan karena pertumbuhan yang baik akan memacu proses fisiologi tanaman. Pertumbuhan vegetatif yang baik tidak terlepas dengan teknik budidaya yang tepat, salah satu cara untuk memacu pertumbuhan vegetatif ini adalah dengan pemberian pupuk Urea.

Tanaman jagung dalam hidupnya membutuhkan unsur Nitrogen dalam jumlah yang cukup dan waktu yang tepat. Nitrogen yang diterima tanaman terutama untuk memperbaiki bagian vegetatifnya terutama daun. Semakin baik pertumbuhan daun maka diharapkan fotosintesis akan berjalan lancar sehingga asimilat yang dihasilkan 
dapat digunakan. Pertumbuhan vegetatif tanaman jagung sangat mendukung terhadap pertumbuhan generatifnya, karena asimilat yang dihasilkan selama fase vegetatif akan disimpan dibagian organ tanaman yang lain sebelum organ generatifnya berkembang. Semakin banyak asimilat yang disimpan maka diharapkan semakin banyak pula asimilat itu ditransfer ke bagian tanaman yang membutuhkan pada waktu pertumbuhan generatif. Permasalahannya apakah dengan pemberian dosis Urea yang semakin tinggi, maka pertumbuhan vegetatif tanaman akan semakin meningkat pula.

Asimilat yang digunakan untuk pengisian biji diperoleh dari tiga sumber utama yaitu fotosintesis daun saat sekarang, fotosintesis bagian lain yang bukan daun saat sekarang, dan remobilisasi hasil asimilasi yang disimpan dalam organ tanaman yang lain ( Gardner et al, 1991 ). Berapa banyak faktor tersebut menyumbang hasil panen biji terakhir dipengaruhi oleh spesies dan lingkungannya.

Bahan kering yang disimpan dalam biji berasal dari daun dan sebagian kecil berasal dari bahan yang tersimpan dalam batang sebagai hasil metabolisme sebelum tanaman berbunga. Oleh karena itu kerusakan daun pada saat berbunga atau setelah tanaman berbunga akan mengurangi suplai bahan kering ke biji. Lupton, ( 1966 ; Wardlaw, 1968 cit Gardner et al., 1991 ) melaporkan bahwa daun-daun sebelah bawah tanaman gandum dan barli memasok kebutuhan batang sebelah bawah dan akar. Apabila daun-daun pucuk dibuang, daundaun sebelah bawah akan memasok hasil asimilasi ke biji; bila daun-daun sebelah bawah dibuang, daun bendera akan mentrasfer hasil asimilasi ke akar ( Marshall dan Wardlaw, 1973 ). Berdasarkan hal ini maka dilakukan pemangkasan daun tanaman jagung. Selain pemangkasan, daun tanaman jagung dapat berkurang atau rusak akibat tiupan angin dan hama pemakan daun pada saat biji sedang berkembang. Permasalahannya apakah dengan pemangkasan tersebut biji tanaman akan berkembang dengan baik ?.

Biji bertambah berat keringnya secara eksponensial pada awal perkembangannya yang diikuti dengan pertambahan berat yang konstan dan cepat sampai mencapai masak fisiologis ( Egli, 1981 ).

Jones and Simmons ( 1983 cit Borras, 2001 ) menemukan bahwa berat biji tidak dipengaruhi oleh meningkatnya penggunaan asimilat per biji, namun berat biji dipengaruhi oleh berkurangnya jumlah biji per tanaman pada akhir periode pembuahan. Sebaliknya Kiniry et al ( 1990 ) melaporkan bahwa berat biji-biji pada posisi tongkol yang sama menigkat dengan berkurangnya jumlah biji per tanaman.

Penelitian ini bertujuan untuk mendapatkan dosis Urea yang dapat memberikan sumbangan asimilat terbesar pada biji jagung yang dipangkas sebagian daun sebelah atas tongkol.

\section{BAHAN DAN METODE}

Bahan yang digunakan adalah : benih jagung varietas Arjuna, pupuk kandang ayam, pupuk Urea, SP 36, $\mathrm{KCl}$, fungisida Dithane $\mathrm{M}-45$, Sevin 85 P.

Alat yang digunakan adalah alat-alat pengolahan tanah, Timbangan analitik, alat-alat 
pemeliharaan tanaman, Komputer, program stx untuk pengolahan data.

Penelitian menggunakan

Rancangan Acak Kelompok dalam faktorial dengan 3 kali ulangan, analisa data menggunakan regresi polinomial ( uji kecendrungan ). Faktor 1 adalah pemangkasan daun yang terdiri dari 3 taraf; yaitu :

$\mathrm{A}=$ Tanpa pemangkasan (Kontrol)

$\mathrm{B}=$ Pemangkasan $1 / 2$ helai daun yang berada di atas tongkol ;

$\mathrm{C}=$ Pemangkasan seluruh organ di atas tongkol

Faktor 2 adalah dosis pupuk Urea yang terdiri dari 4 taraf, yaitu :

$\mathrm{N}_{0}=$ Tanpa pemupukan

$\mathrm{N}_{1}=$ Urea dengan dosis $100 \mathrm{~kg} / \mathrm{ha}$

$\mathrm{N}_{2}=$ Urea dengan dosis $200 \mathrm{~kg} / \mathrm{ha}$

$\mathrm{N}_{3}=$ Urea dengan dosis $300 \mathrm{~kg} / \mathrm{ha}$.

Benih yang digunakan

terlebih dahulu diseleksi. Kemudian ditugal sedalam $3 \mathrm{~cm}$, dengan jarak tanam $75 \mathrm{~cm} \mathrm{x} 40 \mathrm{~cm}$. Setiap lubang tanam dimasukkan 2 biji, setelah seminggu diseleksi dan ditinggalkan satu tanaman per lubang, sehingga terdapat 24 tanaman per unit percobaan.

Lahan yang akan ditanami diberi pupuk kandang dua minggu sebelum penanaman sebanyak 10 ton per hektar. Pupuk kandang diberikan dengan cara ditebar rata kemudian diaduk dengan tanah. Pupuk kandang yang diberikan adalah 270 kg. Sedangkan pupuk Urea diberikan dengan cara ditugal sedalam $10 \mathrm{~cm}$ pada kedua sisi tanaman dengan jarak $15 \mathrm{~cm}$.

Pupuk Urea diberikan dua kali yaitu $1 / 3$ bagian pada saat tanam, kemudian 2/3 bagian diberikan pada waktu berumur 1 bulan. Dosis $100 \mathrm{~kg} / \mathrm{ha}$, kubutuhan pupuk/tanamannya adalah $75 \mathrm{~g} /$ polt, $1 / 3$ nya adalah $25 \mathrm{~g} / \mathrm{plot}$ dan selebihnya diberikan pada umur 1 bulan. Dosisi pupuk $200 \mathrm{~kg} / \mathrm{ha}$ kebutuhan per plotnya adalah $150 \mathrm{~g}$, $1 / 3$ nya adalah $50 \mathrm{~g} / \mathrm{plot}$. Dosis pupuk $300 \mathrm{~kg} / \mathrm{ha}$ kebutuhan per plotnya adalah $225 \mathrm{~g}, 1 / 3$ nya adalah 75 g/plot. SP 36 dan $\mathrm{KCl}$ hanya diberikan pada saat tanam bersama pupuk Urea dengan dosis $100 \mathrm{~kg} / \mathrm{ha}$ ( setara dengan $75 \mathrm{~g} /$ plot SP 36 dan 75 $\mathrm{g} /$ plot $\mathrm{KCl}$ ).

Daun-daun dipangkas setelah terjadi penyerbukan, hal ini ditandai dengan terlihatnya rambut-rambut pada tongkol jagung. Pemangkasan dilakukan apabila $50 \%$ dari tanaman setiap plot telah diserbuki. Berat daun segar yang dipangkas ditimbang dan dirata-ratakan.

Pemeliharaan tanaman meliputi penyiraman, penyisipan dan penjarangan,penyiangan dan pembumbunan, dan pengendalian hama dan penyakit. Tanaman jagung siap dipanen dengan ciri ciri klobot sudah berwarna kuning ( $85 \%$ ), buah jagung bila dikupas bijinya tampak mengkilat dan bila ditekan dengan kuku ibu jari tidak membekas.

Pengamatan dilakukan terhadap ; Jumlah biji per tongkol ( butir); Berat kering biji umur 10, dan 30 hari setelah penyerbukan (BKB), biji jagung yang akan diamati diambil 10 hari, dan sampel kedua 30 hari setelah penyerbukan. Kulit tongkol dibuka dan biji yang berda di bagian tengah tongkol dicongkel dengan obeng sebanyak 15 biji. Kemudian bekas luka disemprot dengan Dithane M - 45 dan kulit kelobot ditutup kembali. Biji dikeringkan dalam oven dengan tempratur $85^{0} \mathrm{C}$ selama 48 jam, kemudian ditimbang berat keringnya, biji yang sudah dipanen dikeringkan di dalam oven dengan tempratur $85^{\circ}$ 
C selama 48 jam kemudian ditimbang berat keringnya;
Kecepatan penimbunan bahan kering ( KPBK ). Dihitung dengan rumus :

\section{BKB $30-$ BKB 10}

\section{$\mathrm{KPBK}=$}

\section{0}

Kecepatan penumpukan bahan kering dinyatakan dalam mg/biji/hari ; dan waktu penimbunan efektif ( hari )

Dihitung dengan rumus : WPE = BBP : KPBK

\section{HASIL DAN PEMBAHASAN}

\section{Hasil Penelitian}

Gambar -gambar berikut tingkat pemangkasan organ bagian memperlihatkan hubungan antara atas tanaman jagung yang dilakukan. dosis Urea yang diberikan dan

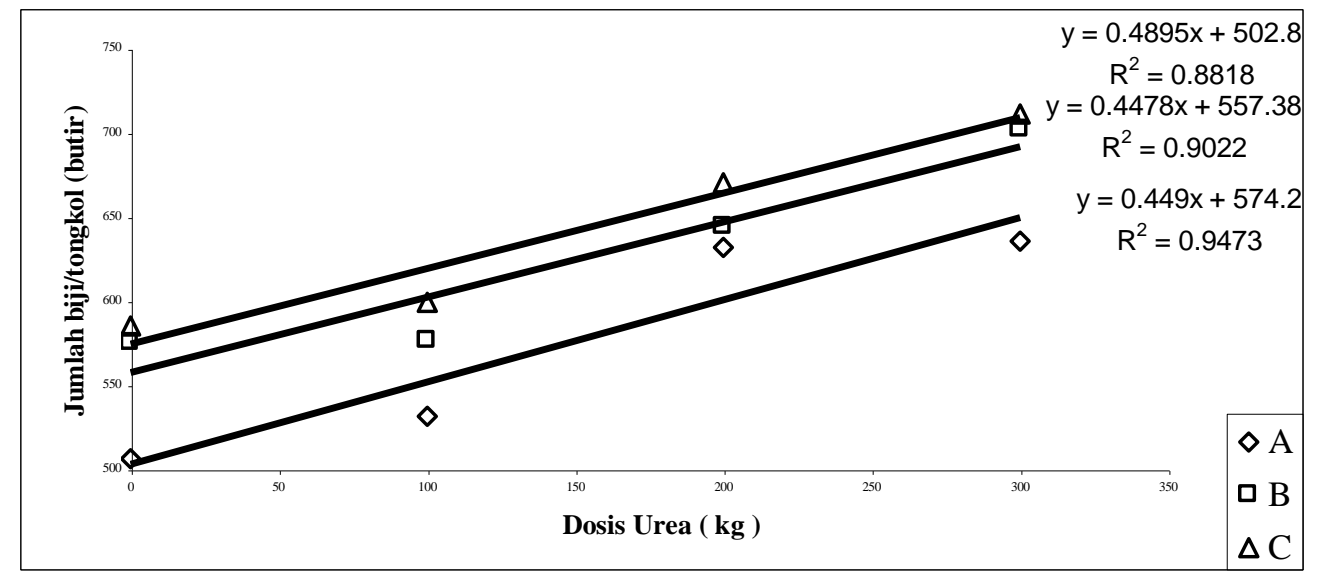

Gambar 1. Grafik hubungan antara pemangkasan tanaman dengan beberapa taraf dosis Urean terhadap jumlah biji per tongkol ( butir )

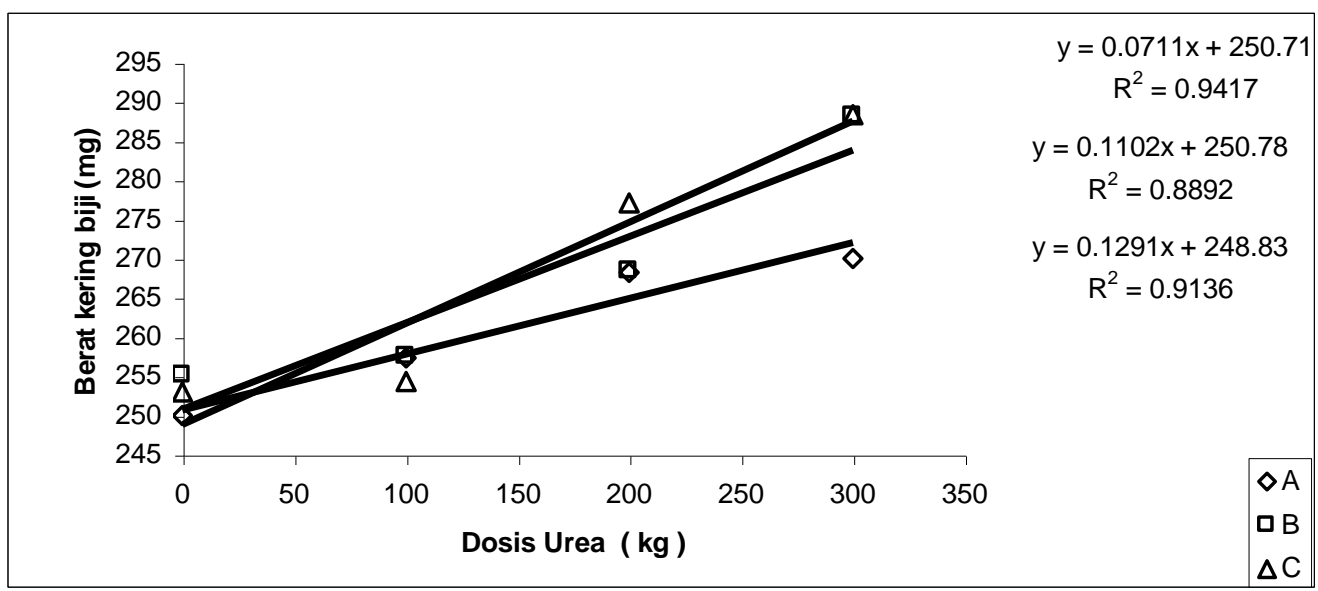

Gambar 2. Grafik hubungan antara pemangkasan dengan dosis Urea terhadap Berat kering biji saat panen. 


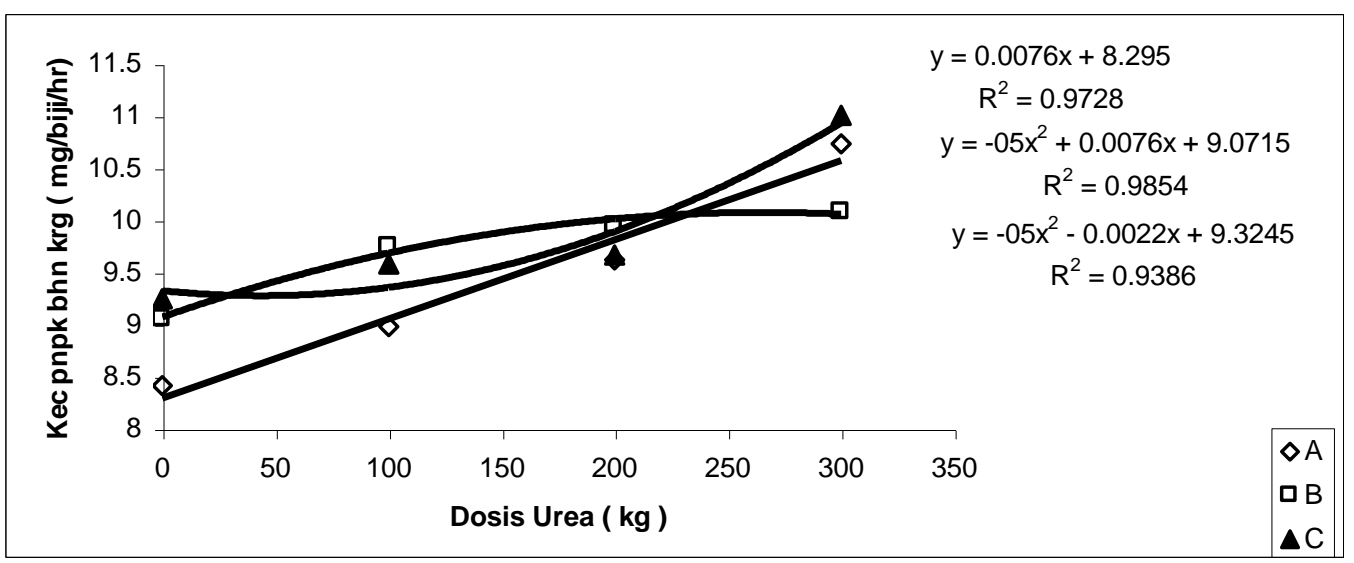

Gambar 3. Grafik hubungan antara pemangkasan dan dosis Urea terhadap kecepatan penimbunan bahan kering biji ( $\mathrm{mg}$ )

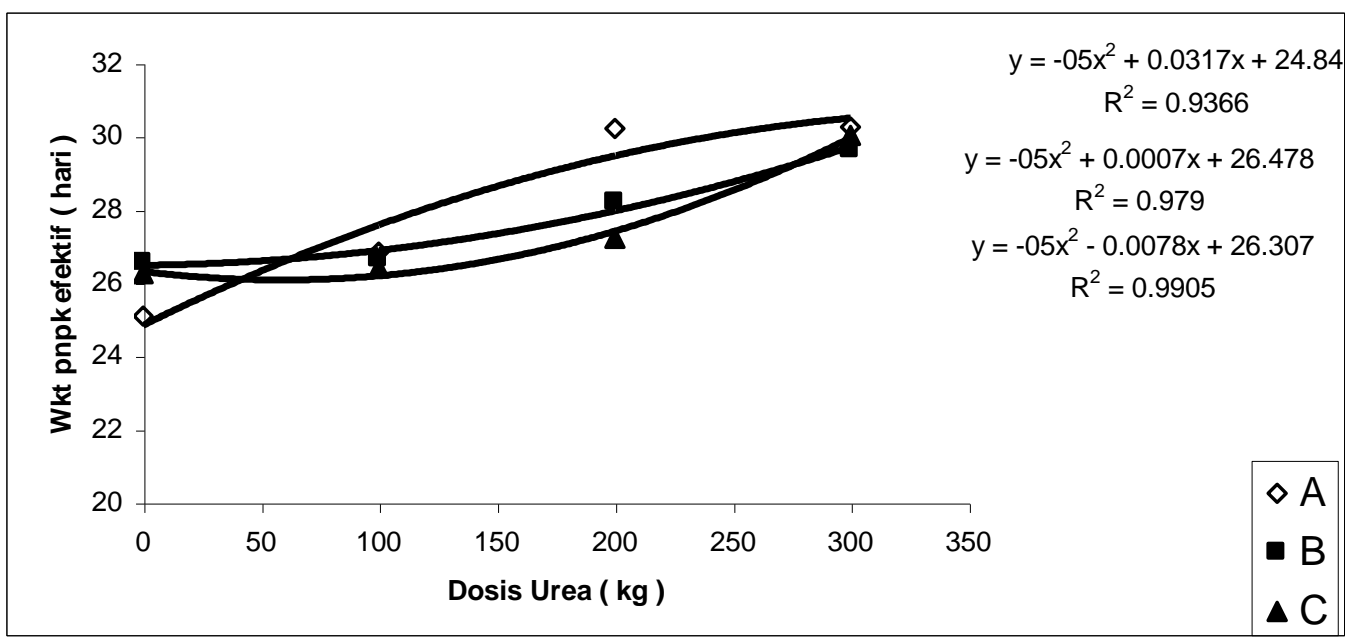

Gambar 4. Grafik hubungan antara pemangkasan dan beberapa taraf dosis Urea terhadap waktu penimbunan bahan kering efektif.

\section{Pembahasan}

Gambar 1. memberikan arti bahwa tanaman yang tidak dipangkas menyumbangkan lebih sedikit bahan kering ke biji pada saat pengisian biji, walaupun diikuti dengan penambahan dosis Urea namun peningkatan bahan kering ke dalam biji masih berada di bawah tanaman yang mengalami pemangkasan. Sedangkan tanaman yang dipangkas $1 / 2$ bagian daun di atas tongkol dengan tanaman yang dipangkas seluruh organ tanaman di atas tongkol tidak berbeda karena kenaikan jumlah biji menunjukkan garis yang sejajar, penambahan dosis Urea untuk kedua taraf pemangkasan memberikan kenaikkan yang sama, semakin besar dosis Urea maka semakin banyak jumlah biji pada tanaman yang mengalami pemangkasan.

Jumlah biji yang lebih besar pada tanaman yang dipangkas memberikan arti bahwa pemangkasan setelah terjadi pembuahan terjadi tidak berpengaruh negatif terhadap produksi jagung. Hal ini disebabkan karena asimilat yang disimpan di dalam organ 
tanaman misalnya batang lebih banyak. Banyaknya asimilat yang dihasilkan karena pertumbuhan tanaman yang diberi pupuk Urea dengan dosis $300 \mathrm{~kg}$ lebih baik terutama daunnya sehingga proses fotosintesis juga berjalan baik, fotosintat yang dihasilkan juga banyak. Pada waktu fase generatif belum dimulai maka fotosintat disimpan di dalam batang tanaman, setelah proses pengisian biji dimulai maka timbunan fotosintat yang ada di batang dikirim ke bagian yang membutuhkan yaitu biji.

Tanaman yang tidak mengalami pemangkasan jumlah biji per tongkol rendah, hal ini diduga karena fotosintat yang dihasilkan pada waktu fase vegetatif, selain digunakan untuk perkembangan biji juga digunakan untuk organ tanaman yang tidak dipangkas, sehingga terjadi kompetisi di dalam tubuh tanaman itu sendiri.

Jumlah biji per tongkol pada penelitian ini didukung oleh Jones dan Simmons ( 1983 ), mereka melaporkan bahwa berkurangnya suplai asimilat yang terjadi sebelum dan sampai awal perkembangan biji menyebabkan terganggunya pembesaran sel embrio dan endosperm.

Gambar 2. menggambarkan peningkatan berat kering dengan meningktanya dosis Urea yang diberikan pada tanaman yang dipangkas seluruh organ tanaman di atas tongkol, sedangkan untuk tanaman yang dipangkas $1 / 2$ bagian daun yang berada di atas tongkol terjadi penurunan berat kering. Dan pada tanaman yang tidak dipangkas berat kering biji justru paling rendah. Hal ini memberi arti bahwa pemangkasan setengah helaian daun bila tidak diimbangi dengan pemberian Urea maka akan menurunkan berat kering biji saat panen. Jelaslah bahwa pupuk Urea yang diberikan kepada tanaman yang dipangkas $1 / 2$ helaian daun mampu meningkatkan berat kering biji saat panen, bila Urea terus ditingkatkan maka berat kering biji juga ikut meningkat. Dari gambar tersebut dapat dilihat bahwa pemupukan sampai $200 \mathrm{~kg}$ memperlihatkan berat kering yang rendah, hal ini disebabkan pertumbuhan vegetatif tanaman di lapangan juga tidak bagus dimana terlihat daunnya lebih kecil jika dibandingkan tanaman yang diberi pupuk dan lebih sedikit. Terhambatnya perkembangan daun menyebabkan permukaan untuk proses fotosintesis menjadi lebih sempit, akibatnya fotosintat yang dihasilkan juga lebih sedikit. Permukaan luas daun yang lebih kecil juga mengakibatkan permukaan transpirasi sedikit sehingga proses penyerapan hara oleh akar juga kecil.

Tanaman yang mengalami pemangkasan seluruh organ di atas tongkol memperlihatkan berat kering biji yang begitu pesat, bila diikuti dengan pemupukan dengan dosis yang lebih tinggi, ini dapat dijelaskan sebagai berikut, tanaman yang dipangkas seluruh bagian daun pada saat pengisian biji tidak membaginya untuk bagian tanaman di atas tongkol. Pada gandum dan barli menunjukkan bahwa fotosintesis dari daun bendera, batang dan bongkol yang merupakan sumber terdekat dengan biji menjadi penyumbang utama, apabila daun sebelah atas dibuang, daun-daun sebelah bawah akan memasok hasil asimilasi ke biji ( Lupton et al , 1966 cit Gardner, 1991 ).

Borras dan Otegui ( 2001 ) melaporkan bahwa ada hubungan 
antara jumlah biji per tongkol dengan berat kering biji, dimana berat kering biji meningkat dengan menurunnya jumlah biji per tongkol, hal ini disebabkan karena biji-biji yang berada dalam satu tongkol juga berkompetisi dalam menggunakan asimilat. Kiniry ( 1988 ) mendapatkan pengurangan biji dapat meningkatkan berat biji.

Gambar 3. Kecepatan penimbunan bahan kering ke dalam biji jagung pada tanaman yang tidak dipangkas menunjukkan hubungan yang linier dengan dosis Urea, sedangkan pada tanaman yang dipangkas $1 / 2$ bagian daun di atas tongkol terlihat kecepatan penimbunan bahan kering ke biji pada dosis Urea rendah juga rendah, peningkatan kecepatan terlihat lebih cepat pada saat tanaman mendapatkan pupuk Urea dengan dosis yang lebih besar, namun pada dosis di atas $200 \mathrm{~kg} / \mathrm{ha}$ terlihat kecepatan penimbunan bahan kering ke biji berjalan lambat, sementara itu pada tanaman yang dipangkas seluruh organ tanaman di atas tongkol dengan pemberian Urea 300 $\mathrm{kg} / \mathrm{ha}$ terjadi peningkatan kecepatan penimbunanan bahan kering. Seperti tanaman yang dipangkas $1 / 2$ bagian daun di atas tongkol, maka pada pemangkasan seluruh bagian di atas tongkol dengan pemberian dosis Urea sampai $100 \mathrm{~kg} / \mathrm{ha}$ kecepatan penimbunan berjalan lambat, kemudian meningkat seiring dengan semakin meningkatnya pupuk Urea yang diberikan. Pada tanaman tanpa dipangkas kecepatan terus meningkat disebabkan karena daun-daun yang tidak dipangkas melakukan transpirasi sehingga laju pengangkutan lebih cepat dibandingkan dengan tanaman yang dipangkas sebagian atau keseluruhan bagian di atas tongkol. Pada tanaman yang dipangkas $1 / 2$ bagian pada dosis Urea $200-300 \mathrm{~kg} / \mathrm{ha}$ menunjukkan laju penimbunan bahan kering yang stabil, hal ini diduga pupuk Urea yang diberikan pada dosis tinggi tidak mampu meningkatkan kecepatan penimbunan bahan kering tersebut, karena sebagian bahan kering digunakan untuk proses respirasi bagi organ yang tidak dipangkas. Sedangkan pada tanaman yang dipangkas seluruh bagian di atas tongkol memperlihatkan laju penimbunan yang semakin cepat pada tanaman yang diberi pupuk Urea di atas $200 \mathrm{~kg} / \mathrm{ha}$, hal ini diduga bahan kering yang sudah tersimpan pada batang hanya dikirim ke biji saja, dugaan lain adalah karena pemangkasan mengakibatkan luka, dan luka biasanya akan menghasilkan etilen dan etilen akan menyebabkan penimbunan hasil asimilasi kebagian luka, sementara tongkol jagung yang berada di bagian atas merupakan daerah pemanfaatan yang sangat membutuhkan pasokan asimilat. Penimbunan asimilat di daeah pemanfaatan mengakibatkan osmosis daerah ini menjadi tinggi sehingga asimilat dari daerah sumber bergerak lebih cepat kedarah pemanfaatan yaitu biji. Gardner et al., ( 1991 ) menyatakan bahwa pembongkaran muatan floem menurunkan konsentrasi gula dalam pembuluh tapis, penimbunan gula pada daerah sumber dan pengambilan gula di daerah pemanfaatan menimbulkan landaian tekanan hidrostatik yang menghantar air dan gula dari sumber ke daerah pemanfaatan.

Gambar 4. memperlihatkan waktu penimbunan bahan kering efektif pada tanaman yang dipangkas 
dan diberi Urea. Pada gambar tersebut tanaman yang tidak dipangkas dan diberi Urea cenderung menunjukkan garis linier sedangkan tanaman yang dipangkas dan diberi Urea cenderung menunjukkan hubungan yang kuadratik. Gambar 4. ada hubungan antara kecepatan penimbunan bahan kering dengan waktu penimbunan yang efektif. Pada tanaman yang tidak dipangkas waktu penimbunan bahan kering lebih lama dibandingkan dengan tanaman yang dipangkas. Untuk tanaman yang dipangkas waktu yang dibutuhkan untuk menimbun bahan kering lebih cepat, hal ini diduga karena biji sudah tidak mampu lagi menerima pasokan asimilat. Dugaan lain bahwa asimilat yang akan dikirim ke biji sudah habis. Bila biji sudah tidak mampu lagi menerima pasokan asimilat maka akan mempengaruhi proses fotosintesis karena fotosintat yang dihasilkan tidak dapat dimanfaatkan dan akan mengurangi proses fotosintesis itu sendiri. Mondal et al ( 1978 ) melaporkan bahwa apabila daerah pemanfaatan tidak dapat memanfaatkan hasil fotosintesis yang meningkat, akan terjadi penimbunan gula yang terus menerus dalam sistem, dan menjadi suatu hambatan

\section{KESIMPULAN DAN SARAN}

\section{A.Kesimpulan}

Biji jagung yang dihasilkan oleh tanaman yang tidak dipangkas dan tidak diberi pupuk Urea lebih rendah dalam hal jumlah biji per tongkol, berat kering biji saat panen, kecepatan penumpukan bahan kering ke biji, dan waktu penumpukan behan kering ke biji, namun apabila diikuti dengan pemupukan Urea umpan balik yang berakibat pengurangan fotosintesis. Pada tanaman jagung yang dipangkas waktu panennya lebih cepat dibandingkan dengan tanaman yang tidak dipangkas, hal inilah yang diduga dapat memperkuat temuan Mondal et al tersebut. Daun yang masih tertinggal sudah tidak mampu memasok asimilat karena biji sudah tidak mampu menerima. Kalau ditinjau dari biji jagung, maka kemampuan menampung asimilat ini disebabkan oleh faktor genetik. Pada Gambar 2. berat kering biji itu diperoleh dari tanaman yang dipangkas $1 / 2$ bagian daun di atas tongkol dan seluruh bagian daun di atas tongkol, jadi dalam hal ini penjelasan yang mengatakan bahwa biji tidak mampu lagi menerima asimilat lebih logis.

Pemberian Urea dosis 200 $300 \mathrm{~kg} / \mathrm{ha}$ memperpanjang waktu pengisian biji efektif dan pada saat ini tanaman jagung sudah memenuhi kriteria panen. Secara umum dapat dikatakan bahwa pemangkasan pada tanaman jagung bila diikuti dengan pemupukan Urea dapat meningkatkan produksi jagung. Sehingga hasil pemangkasan dapat digunakan sebagai pakan ternak.

maka seluruh parameter yang disebutkan tadi akan meningkat.

Produksi biji pada tanaman yang dipangkas $1 / 2$ bagian daun di atas tongkol lebih tinggi dinadingkan tanaman yang tidak dipangkas dengan pemberian pupuk Urea yang sama. Peningkatan terjadi terhadap jumlah biji per tongkol, berat kering biji saat panen, namun kecepatan penimbunan bahan kering semakin 
lambat dengan meningkatnya pupuk. Begitu juga pada waktu penimbunan bahan kering maka waktu yang terlama didapat pada tanaman yang diberi Urea $300 \mathrm{~kg} / \mathrm{ha}$.

Produksi biji pada tanaman yang dipangkas seluruh bagian tanaman di atas tongkol memperlihatkan hal yang sama dengan tanaman yang dipangkas $1 / 2$ bagian di atas tongkol untuk jumlah biji tongkol, namun terjadi peningkatan berat biji kering per tongkol, dan kecepatan penimbunan bahan kering, sementara untuk waktu penimbunan bahan kering antara tanaman yang dipangkas sebagian dan tanaman yang dipangkas seluruh bagian, waktu penimbunan bahan kering dianggap sama apabila tanaman diberi pupuk Urea 300 $\mathrm{kg} / \mathrm{ha}$.

\section{Saran}

Daun-daun tanaman jagung dan organ lain yang ada di atas tongkol dapat dipangkas seluruhnya, sehingga dapat dijadikan tambahan pakan ternak, tetapi perlu penambahan pupuk Urea sebanyak $300 \mathrm{~kg} / \mathrm{ha}$ dalam pembudidayaannya.

\section{DAFTAR PUSTAKA}

Borras, L., M. Otegui, 2001. Maize kernel weight response to postflowering source - sink ratio. Crop Sci. 49 : $1816-$ 1822.

Egli, D. B. 1981. Species difference in seed characteristic. Field Crop Res. 4 : $1-12$.

Gardner, F. P., R. Brent Perce, Roger L. Mitchell, 1991. alih bahasa Herawati Susilo. Fisiologi Tanaman Budidaya. Universitas Indonesia.

Jones, R. J., S. R. Simmons, 1983. Effect of altered source sink ratio on growth of maize kernels. Crop sci. 23 : $129-$ 134.

Kiniry, J. R. 1988. Kernel weight increase in response to decreased kernel number in sorghum. Agron. J. $80: 221$ $-226$.

Kiniry, J. R., C. A. Wood, D. A. Spanel, dan A. J. Bockhoft, 1990. Seed weight respons to decreased seed number in maize. Agron. J. 54 : $98-$ 102.

Lupton, F. G. H., 1966. Ann. Appl. Biol 57 : $355-64$

Marshall, C., dan I. F. Wardlaw, 1973. Aust. J. Biol. Sci. 26 $: 1-13$.

Mondal, M. H., W. A. Brun, dan M. L. Brenner, 1978. Plant Physiol. 61 : $394-97$. 